\title{
Redakteursbrief: Festschrift vir Wannie Carstens
}

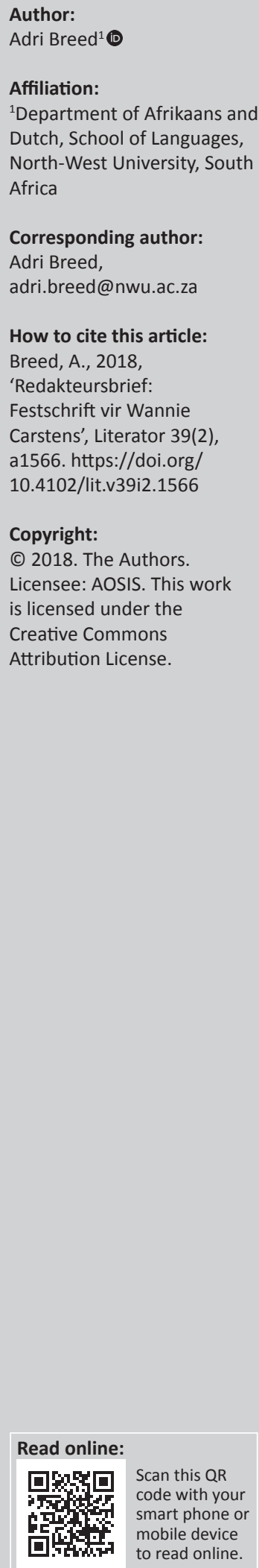

Prof. Wannie Carstens het aan die einde van 2017 afgetree na 'n suksesvolle loopbaan as Afrikaanse taalkundige. Die redaksie van Literator - waarvan hy 'n redaksionele medewerker is - dra graag hierdie huldigingsuitgawe aan hom op.

Wannie was die afgelope jare veral aktief betrokke in die velde van Afrikaanse taalgeskiedenis, teksredaksie en tekslinguistiek. Verder het hy ook vir 15 jaar as die direkteur van die Skool vir Tale van die Noordwes-Universiteit se Potchefstroomkampus gedien. Selfs ná sy aftrede bly hy nog aktief betrokke in die Afrikaanse akademie deur onder meer nog in 2018 as gasdosent van Afrikaanse Taalkunde in Leiden (Nederland) op te tree, en in dieselfde jaar die Leerstoel ZuidAfrika van UGent in België te beklee.

As prominente figuur binne die breër Afrikaanse taalgemeenskap het hy ' $n$ hele paar belangrike funksies verrig. Hy is naamlik een van die stigterslede van die Afrikaanse Taalraad, en dien ook tot November 2011 as voorsitter van hierdie organisasie. Ook van ánder Afrikaanse organisasies tree hy vir etlike termyne as voorsitter op, naamlik die Nasionale Taalliggaam vir Afrikaans (NTLA), die Raad van die SA Akademie vir Wetenskap en Kuns en die Raad van die Afrikaanse Taalmuseum en -monument. Hy dien vir agt jaar op die Direksie van die Buro van die Woordeboek van die Afrikaanse Taal (WAT). Vir byna twee jaar dien hy as ondervoorsitter van die Pan-SuidAfrikaanse Taalraad (PanSAT). Tans is hy die ondervoorsitter van die Afrikaanse Taalmuseum en -monument se Raad en dien hy vir 'n tweede termyn op die Raad van die Universiteit Stellenbosch.

Wannie is betrokke by 'n hele aantal instansies, inisiatiewe en projekte wat Afrikaans in die buiteland bevorder. Enkele voorbeelde hiervan is die vestiging en instandhouding van die Ernst van Heerden-versameling van Afrikaanse poësie in die Poëziecentrum in Gent, sowel as die Festival voor het Afrikaans in Amsterdam. Hy is ook verantwoordelik vir die sluit van 'n aantal uitruil- en samewerkingsooreenkomste wat Afrikaans as vak aan verskeie Europese universiteite gevestig het soos in Antwerpen en Gent (België), Leiden (Nederland) en Wene (Oostenryk).

Vanweë die feit dat hy gedurende sy akademiese loopbaan op soveel vlakke en in soveel verskillende hoedanighede by Afrikaans betrokke was, was dit besonder uitdagend om 'n seleksie te maak van moontlike outeurs wat genooi moet word om 'n bydrae tot hierdie uitgawe te maak. Hoewel daar soveel ander van Wannie se medewerkers, kollegas, oudstudente en vriende is wat sekerlik ook eintlik by hierdie uitgawe betrek sou moes word, wou ons graag vir hierdie huldiging 'n versameling aanbied wat veral drié fasette van Wannie se loopbaan uitlig.

Die eerste en belangrikste kom sy rol as akademikus aan bod - spesifiek sy bydrae tot bepaalde vakgebiede binne die Afrikaanse Taalkunde. Wannie was 'n aktiewe navorser in die velde van taalgeskiedenis en taalnorme. Vyf akademiese artikels rondom hierdie onderwerpe is in die uitgawe opgeneem, naamlik dié van Kris van de Poel, Rufus Gouws, Angelique van Niekerk, Jaap Steyn, en Christo van Rensburg (wat 'n week voor sy afsterwe die bydrae afgehandel het).

Drie van hierdie artikels betrek taalnorme. Kris van de Poel se artikel, getiteld 'From pencil and eraser to blending materials and flipping the classroom: A short history of Teksredaksie and Text editing', beskryf die beplanning en uitvoering van Van de Poel en Carstens se publikasie: Teksredaksie (asook die boek se vertaling in ander tale). Ook die implementering van die boek in taalonderrig word in die artikel bespreek. Die artikel van Rufus Gouws, 'Woordeboekdidaktiek in 'n omvattende woordeboekkultuur', argumenteer dat leksikografie deel van 'n kurrikulum vir taalkundestudente moet uitmaak. Waar Van de Poel en Gouws se artikels hoofsaaklik op taalnorme binne 'n taalonderrigkonteks aangebied word, bekyk die artikel van Angelique van Niekerk, 'Die intensionele afwyking op die norme van Standaardafrikaans in advertensies', 
vanuit 'n tekslinguistiese perspektief die wyse waarop Afrikaanse taalnorme gehandhaaf word - of juis nié gehandhaaf word nie - in gedrukte advertensiemateriaal met die doel om die aanvaarbaarheid van die boodskap in die taalgemeenskap te verhoog.

Artikels van twee van Wannie se eweknieë as taalgeskiedeniskenners is ingesluit. Jaap Steyn se artikel, 'Politieke strategieë van aktiviste vir die amptelike erkenning van Afrikaans', bekyk die politieke strategieë wat vyf spesifieke taalstryders in die tydperk 1875 tot 1925 gevolg het in 'n poging dat Afrikaans as amptelike taal erken word. Die artikel van Christo van Rensburg, 'Toe die vierde Taalkommissie in sy spore gestuit is', beskryf ' $n$ tydperk in die geskiedenis van die Afrikaanse Woordelys en Spelreëls (1930-1932) toe daar vanweë regeringsbesluite wat geïmplementeer moes word, onsekerheid by die taalgemeenskap ontstaan het oor die wyse waarop sekere Afrikaanse woorde gespel moet word.

Tweedens het Wannie 'n belangrike rol in die NoordwesUniversiteit se Skool vir Tale gespeel - enersyds vakkundig, en andersyds op bestuursvlak in die skool en in die breër universiteitsomgewing. Gegewe Wannie se intensiewe betrokkenheid by die Noordwes-Universiteit (NWU), het die inisiatief vanuit eie geledere gekom om hierdie huldigingsbundel saam te stel. Derhalwe was Literator ook die aangewese publikasietuiste. Drie akademiese artikels in hierdie uitgawe is deur Afrikaanse taalkundiges van die NWU, te wete Daan Wissing (een artikel) en Gerhard van Huyssteen ('n tweetal artikels) gelewer.

Daan Wissing se artikel, 'Die ontwikkeling van [J] in Afrikaans', lewer verslag van 'n ondersoek na die Afrikaanse konsonantsisteem. In hierdie artikel word verdere kontekste ondersoek waarin die stemlose alveolêre frikatief /s/, geproduseer word as [J] wanneer dit onmiddellik gevolg word deur ' $n$ /r/, maar as [s] geproduseer word in ander kontekste. In 'n tweetal artikels bekyk Gerhard van Huyssteen die kontroversiële Afrikaanse woord, huidiglik, vanuit twee perspektiewe. In die eerste artikel, 'Norme vir huidiglik', word 'n omvattende literatuuroorsig aangebied oor die standpunt(e) wat in Afrikaanse normatiewe bronne gehandhaaf word oor die gebruik van hierdie woord. In die tweede artikel, getiteld "n Korpusondersoek na huidiglik', word die werklike gebruik van huidiglik deur Afrikaanssprekendes met behulp van 'n korpusgebaseerde ondersoek bestudeer.

Soos reeds genoem, het Wannie op verskeie vlakke as plaaslike en internasionale segsman vir Afrikaans opgetree. Om hierdie rede het ons derdens enkele van Wannie se nabykollegas genooi om bydraes te lewer wat nie noodwendig navorsingsbydraes hoef te wees nie. Twee essays is in hierdie bundel opgeneem, naamlik dié van Jacques van Keymeulen en Michael le Cordeur, wat oor 'n onderwerp handel waarby Wannie regdeur sy hele loopbaan aktief betrokke was, naamlik taalpolitiek. Aangesien Wannie ook by die vestiging van Afrikaanse literêre projekte in die buiteland betrokke was, het ons ook bydraes van twee van Wannie se kollegas uit die Afrikaanse letterkundegemeenskap in hierdie bundel as Litera opgeneem, naamlik 'n kortverhaal van Ena Jansen en 'n gedig van Hennie van Coller.

Die impak wat Wannie Carstens gedurende sy loopbaan gemaak het en die rimpeleffek wat sy verskeie en uiteenlopende inisiatiewe steeds op Afrikaans en die Afrikaanse taalkundegemeenskap het, kan moeilik in woorde beskryf word. Hierdie huldigingsuitgawe is maar een poging om erkenning te gee aan die passie en invloed van waarskynlik een van ons tyd se grootste taalambassadeurs. 